\title{
Penyebaran Link Phising Kuota Kemendikbud Terhadap Kesadaran Informasi Pribadi Di Kalangan Mahasiswa UNINUS
}

\author{
Akmal Ramadhan', Muhammad Alwi Alhafidh'2, Muhamad Diki Firmansyah ${ }^{3}$ \\ 1,2,3 Program Studi IImu Komunikasi, Fakultas IImu komunikasi, Universitas Islam Nusantara
}

$\begin{array}{r}\hline \text { A R T I C L E I N F O } \\ \hline \text { Article history: } \\ \text { Received Sep 9, } 2021 \\ \text { Revised Sep 20, } 2021 \\ \text { Accepted Jan 22, } 2022 \\ \hline\end{array}$

Keywords:

Phishing Link; Quota Kemendikbud; Information.

\begin{abstract}
Hoaxes are becoming one of the things that are increasingly found in todays digital era. The types of hoaxes circulating in the community are also very diverse, one of which is the Ministry of Education and Culture quota phishing link hoax. This hoax is targeting the personal data of students and people who need internet quota during this pandemic. For this reason, we want to find out how aware Uninus students are about the importance of personal data security. This study uses descriptive approach, and data collection technique is through interviews and questionnaires. This type of research data is primary data, and the research subjects are Uninus students. The object of this research is the awareness of Uninus students towards personal information, the informants are class $A$ students of the Communication Studies study program. As a result, the informants admitted that they had received phishing links from the Ministry of Education and Culture quota and knew that phishing links could threaten personal data and could also cause material and non-material losses. They also know the steps to avoid becoming a victim of phishing links and the informants admitted that they are very aware of the importance of personal information security.
\end{abstract}

\section{ABSTRAK}

Hoax menjadi salah satu hal yang semakin banyak ditemukan di era digital saat ini. Jenis hoax yang beredar di masyarakat pun sangat bermacammacam, salah satunya adalah hoax link phising kuota Kemendikbud. Hoax ini mengincar data pribadi para pelajar, mahasiswa, dan orang-orang yang membutuhkan kuota internet di masa pandemi ini. Untuk itulah, dalam penelitian ini kami ingin mengetahui seberapa sadar para mahasiswa Uninus terhadap pentingnya keamanan data pribadi. Penelitian ini menggunakan pendekatan kualitatif dengan metode deskriptif, dan teknik pengambilan datanya melalui wawancara juga quisioner. Jenis data penelitian ini adalah data primer, dan subjek penelitiannya adalah mahasiswa Uninus. Objek penelitian ini adalah kesadaran mahasiswa Uninus terhadap infomasi pribadi, dan informannya adalah para mahasiswa kelas A prodi IImu Komunikasi. Hasilnya, para informan mengaku mereka pernah menerima link phising kuota kemendikbud dan mengetahui bahwa link phising dapat mengancam data pribadi juga bisa menimbulkan kerugian materi maupun non materi. Mereka juga mengetahui langkah-langkah agar tidak menjadi korban link phising dan cara mengenali link phising yang beredar di tengah masyarakat. Para informan mengaku bahwa mereka sangat sadar akan pentingnya keamanan informasi pribadi.

This is an open access article under the CC BY-NC license.

\section{Corresponding Author:}

Akmal Ramadhan

Program Studi IImu Komunikasi, Fakultas IImu komunikasi, Universitas Islam Nusantara,

Jl. Soekarno-Hatta No.530, Sekejati, Kota Bandung, Jawa Barat 40286

Email: ramaakmal5@gmail.com 


\section{PENDAHULUAN}

Pada zaman sekarang yang lebih dikenal dengan era 4.0, yang mana kita harus mempersiapkan diri dengan era 5.0. Kita di tuntut agar bisa mengenal dan menguasai teknologi yang sudah sangat jauh perkembangannya. Yang tadinya pegawai pabrik karyawan harus digantikan oleh mesin robot karena sudah berkembangya teknologi yang sangat pesat, Yang tadinya jika mau bertemu saudara harus bertemu langsung sekarang hanya tinggal menggunakan teknologi smartphone dengan panggilan jarak jauhnya. Seperti yang di katakan Zuria, F.S \& Totok suyanto (2018:565). Perkembangan teknologi dan informasi menjadi bagian bagi seluruh masyarakat dunia, terutama pada saat kemunculan internet. Internet memberi perubahan besar dalam kehidupan masyrakat, dengan adanya internet maka memudahkan dalam mendapatkan informasi dan berkomunikasi dengan cepat dan murah. Namun, dari penggunaan teknologi tersebut pasti ada sisi positif dan negative nya.

Jika kita tidak bisa memanfaatkan teknologi sebaik mungkin, akan sangat banyak sisi negatifnya. Dengan adanya internet juga mampu membawa dampak negatif, karena beberapa informasi di internet dibuat untuk bertujuan memprovokasi sehingga memunculkan konflik di masyarakat. Isi berita biasanya dibuat berdasarkan pemikiran seseorang semata dan beberapa berita yang di muat di internet tidak dapat dipastikan kebenarannya, sehingga berita kerap kali memuat berita bohong atau hoax dan ujaran kebencian. Zuria, F.S \& Totok suyanto (2018:566) contohnya seperti adanya hoax di media sosial yang mana seluruh dunia menggunakan media sosial, dan hanya beberapa persen saja yang tidak tau media sosial. Mungkin sekarang pribahasa "Bahasa lebih tajam dari sebilah pedang" kurang pas jika menjadi acuan dalam kehidupan bermasyarakat, akan lebih pantas jika " ketikan jarimu lebih tajam dari sebilah pedang " mengapa saya berani berkata demikian? Karena hoax di media sangat berbahaya, bisa menimbulkan propaganda, adu domba, hingga kerugian.

Menurut Herlina. M \& Arbi Cristional Lokananta (2018:103) Istilah Hoax menggambarkan suatu informasi bohong, fitnah, atau sejenisnya. Pada mulanya berita hoax sering menimpa golongan artis-artis atau public figure di media sosial yang lekat oleh informasi-informasi bohong dan simpang siur yang belum jelas kebenarannya. Di Indonesia sendiri istilah Hoax sendiri sudah banyak digunakan oleh media-media infotainment pada informasi-informasi selebriti atau public figure agar dapat menaikan rating media infotament tersebut. Pada zaman yang penuh dengan media sosial, istilah Hoax semakin dikenal dengan semakin mudahnya mecari berita berita pada media sosial maupun situs-situs informasi. Sejak saat itu pemberitaan yang masih menjadi simpang siur kebenaraanya sering di katakana sebagai berita hoax. Seperti yang kita ketahui sekarang ini oknum yang menyebarkan berita berita hoax tidak hanya ditujukan untuk public figure saja, banyak sekali sasarannya, ada yang ingin menjatuhkan seseorang, instansi, golongan, kelompok, dan lain lain. Peredaran berita hoax mudah terjadi, terutama di masyarakat yang tingkat literasinya masih sangat rendah. Biasanya, mereka mudah menerima minformasi begitu saja tanpa mencari tahu kebenaran informasi tersebut. Mereka bahkan membagikan atau men-share tanpa mempertimbangkan akibat informasi yang diterimanya. Masyarakat akhirnya termakan berita tersebut dalam kesimpangsiuran berita, provokasi dan rasa saling curiga (Maulana Luthfi, 2017:210).

Hoax menjadi salah satu musuh besar bagi seluruh masyarakat di zaman ini. Jenisnya pun banyak sekali, seperti konten palsu, berita sesat, konten yang di manipulasi, hingga link palsu atau biasa disebut link phising. Phising merupakan kegiatan seseorang yang bertujuan untuk mendapatkan informasi pribadi pengguna internet dengan cara menipu seseorang tersebut menggunakan web palsu yang tampilannya hampir serupa dengan web yang sebenarnya (Wibowo, M.H \& N. Fatimah, 2017:1).

Phising menjadi salah satu jenis hoaks yang sering muncul di internet. Menurut Wibowo dan Fatimah (2017:1), phising merupakan salah satu jenis kejahatan siber, yang saat ini kerap terjadi lewat jaringan komputer. Biasanya, link phising disebarkan dengan iming-iming yang menarik, agar masyarakat tergiur untuk membuka link tersebut dan menyerahkan informasi pribadinya. Salah satu link phising yang sering kali muncul adalah Link Bantuan Kuota Kemendikbud.

Seperti yang kita ketahui, bahwa selama masa Pandemi Covid-19, pemerintah melarang adanya kegiatan berkerumun, termasuk sekolah. Dan karena itulah pemerintah mensosialisasikan 
kegiatan belajar mengajar lewat daring dan memberikan subsidi kuota gratis untuk menunjang kegiatan pembelajaran ini. Sayangnya, fenomena ini dimanfaatkan oleh para penjahat siber untuk meraup keuntungan lewat informasi pribadi para pengguna. Disamping itu, kesadaran masyarakat akan informasi pribadi pun masih sangat buruk. Banyak dari masyarakat yang tidak terlalu memperdulikan ancaman sejenis itu, dan menganggap bahwa hal tersebut merupakan hal sepele dan tak perlu di risaukan (Wibowo, M.H \& N. Fatimah, 2017:2)

Informasi Pribadi merupakan salah satu hal yang sangat penting dalam kehidupan seorang manusia, karena informasi tersebut menyangkut hal-hal yang sangat sensitif dan sudah seharusnya hanya diketahui oleh diri sendiri. Informasi pribadi mencakup beberapa hal, seperti nama lengkap, tempat dan tanggal lahir, alamat rumah, nomor induk kependudukan, nomor handphone, dan lain sebagainya. Data-data inilah yang sudah sepatutnya menjadi privasi dan di lindungi. Jika tidak, bisa menimbulkan penyalahgunaan data dan dapat menjadi kerugian. Kasuskasus yang bisa timbul akibat pencurian informasi pribadi adalah hacking, spaming email, tindak penipuan, manipulasi data, penyadapan data, dan lain-lain (Aswandi, R \& Muchin, P.R.N, 2020:169)

Kesadaran akan pentingnya kerahasiaan informasi pribadi sudah sepatutnya menjadi tanggung jawab setiap individu, tak terkecuali para generasi intelektual seperti Mahasiswa. Menurut Huluwati, W \& Djibran, M.R (2018:73) Mahasiswa adalah seseorang yang memasuki usia dewasa, dan pada masa tersebut mempunyai tanggung jawab atas kehidupan dan perkembangannya. Mahasiswa juga bisa diartikan sebagai orang yang tengah menimba ilmu di suatu perguruan tinggi. Saat ini, seluruh aktivitas mahasiswa melibatkan proses teknologi, seperti membuat rekening bank, mendaftar universitas, perkuliahan, dan lain-lain. Tetapi, meskipun kebanyakan aktivitasnya menggunakan teknologi, tak dapat dipungkiri bahwa masih banyak yang belum peduli terhadap keamanan data pribadi.

Karena itulah, kami tertarik untuk meneliti seberapa sadar para generasi millenial khususnya mahasiswa terhadap pentingnya keamanan data pribadi. Apalagi, generasi millenial adalah generasi yang akan seterusnya hidup berdampingan dengan kemajuan teknologi. Penelitian ini juga di dasari dengan fakta bahwa kejahatan cyber seperti menyebarkan link phising semakin banyak jumlahnya dari waktu ke waktu. Edukasi dan sosialisasi menjadi salah satu jalan untuk mengurangi kemungkinan terjadinya kejahatan cyber terhadap para generasi millenial. Penelitian terdahulu pernah mengangkat keefektifitas edukasi ancaman data pribadi di media sosial ini. Hasilnya, edukasi menggunakan format video tersebut menunjukan hasil yang sukses, dimana $89 \%$ diantaranya mengaku menjadi teredukasi lewat tayangan tersebut (Pane., et al, 2021:417)

Meskipun fenomena ancaman data pribadi pernah diangkat oleh penelitian terdahulu tersebut, bahasan utama antara penelitian ini dengan penelitian tersebut sangat berbeda. Penelitian ini ingin mengetahui tentang seberapa sadarkah para mahasiswa UNINUS sebagai generasi millenial terhadap ancaman pribadi yang mengancam lewat link phising yang tersebar luas di media sosial.

\section{METODE PENELITIAN}

Penelitian ini menggunakan pendekatan penelitian kualitatif. Menurut Gumilang, S. G (2016:145), penelitian kualitatif adalah suatu metode berganda dalam fokus, yang melibatkan suatu pendekatan interpretative dan wajib terhadap pokok permasalahannya dan juga penelitian ini bekerja secara alami yang berupaya memahami dan memberikan tafsiran pada fenomena yang di berikan orang kepadanya. Selain itu, penelitian ini juga menggunakan metode penelitian deskriptif kualitatif. Sebagaimana dijelaskan Zaluchu, E. S (2021:256), metode penelitian deskriptif kualitatif biasanya disajikan secara deskriptif dan bersifat relatif, teoritis dan banyak menggunakan analisis teoritik.

Penelitian ini berusaha menggambarkan fenomena yang terjadi di zaman sekarang, dengan fokus penelitian mengenai Dampak Penyebaran Link Phising Kuota Kemendikbud Terhadap Kesadaran Informasi Pribadi di Kalangan Mahasiswa UNINUS. Sumber penelitian ini menggunakan data premier, yaitu merupakan data yang diperoleh dari penyebaran kuisioner penelitian yang ditunjukan pada sampel penelitian (Budiarto samsul 2020:16). 
Subjek penelitian ini adalah orang yang berstatus dan terdaftar sebagai Mahasiswa Universitas Islam Nusantara. Sedangkan objek penelitian ini adalah kesadaran mahasiswa mengenai informasi pribadi. Informan dari penelitian ini adalah spesifik mahasiswa kelas A prodi IImu Komunikasi Uninus yang berjumlah 31 orang. Teknik pengumpulan data pada penelitian ini menggunakan teknik wawancara dan quisioner.

Penelitian ini juga menggunakan teknik analisis data. Menurut Rizali, A (2019:84) analisis data merupakan upaya untuk yaitu mencari data di lapangan, menata hasil yang ditemukan di lapangan secara sistematis, menyajikan hasil temuan lapangan, dan mencari makna atau kesimpulan. Lebih spesifik, kami menggunakan analisis data model Miles dan Hubberman. Menurut Miles dan Hubberman, (dalam Hardani, et al 2020:163) analisis data terbagi menjadi 3 alur, yaitu reduksi data, penyajian data, dan penarikan kesimpulan.

\section{HASIL DAN PEMBAHASAN}

Di era seperti sekarang ini, kita sudah seharusnya sadar terhadap bahaya yang mengancam dari pencurian data pribadi. Apalagi di tengah pandemi yang mana kebutuhan akan kuota internet semakin meningkat, penyebaran link phising kuota kemendikbud semakin marak tersebar di tengah-tengah masyarakat. Penyebaran link tersebut menyasar para anak muda yang masih bersekolah dan para mahasiswa yang membutuhkan kuota untuk belajar dan kuliah.

Maka dari itu, penelitian ini berusaha untuk mengetahui dampak penyebaran kuota kemendikbud terhadap kesadaran informasi mahasiswa Universitas Islam Nusantara. Dari data yang berhasil kami kumpulkan, kami memilih 2 informan yang jawabannya mewakili seluruh informan yang telah di wawancarai dan mengisi quisioner. Informan tersebut kami samarkan nama nya menjadi inisial demi kenyamanan bersama.

Yang pertama, kami bertanya mengenai penyebaran link phising kuota Kemendikbud terhadap informan. Dan jawaban dari informan A dan B menyatakan bahwa mereka "pernah menerima" link phising kuota Kemendikbud dari grup sosial media WhatsApp dan personal chat dari teman-temannya. Dari pernyataan tersebut, dapat di ketahui bahwa penyebaran link kuota kemendikbud sangat luas di media sosial masyarakat dan banyak yang terkena hoax tersebut. Ini sejalan dengan Juditha (2018:32) bahwa media sosial menjadi tempat yang paling banyak penyebaran hoax.

Yang kedua, kami bertanya mengenai pengalaman para informan setelah menerima link phising Kuota Kemendikbud.

Menurut jawaban yang dikemukakan oleh Informan A :

"Waspada, persepsi pertama penipuan"

Menurut jawaban yang dikemukakan oleh Informan B :

"Pertamanya jadi tanda tanya besar kan, "ini bener apa ngga ya?" terus kek mikir gini "coba aja deh, kali aja bneran" tpi kesini-sini jadi tau kalo itu web palsu, jdi lebih ke "oyaudah yang ini palsu, berarti aku gaboleh isi ini karena bahaya"

Dari pernyataan informan A di atas, bisa di katakan bahwa informan memiliki kecurigaan terhadap link yang diterima nya. Dirinya bahkan mengetahui bahwa link tersebut adalah link penipuan yang dapat membahayakan informasi pribadinya. Berbeda dengan informan B yang awalnya tidak mengetahui secara bahaya apa yang mengintai nya. Dan dirinya baru sadar ketika ia tahu bahwa web tersebut adalah web palsu seiring berjalannya waktu. Hal yang dialami oleh informan B memang sangat sering terjadi terhadap orang-orang yang belum tersadar akan ciri-ciri web palsu dengan yang asli. Inilah yang menjadi celah sekaligus kesempatan para penjahat internet, yaitu memanfaatkan kepolosan para pengguna internet. Ini selaras dengan Rachmawati (2014:211) bahwa phisher memanfaatkan ketidaktelitian user juga kecerobohan para user dalam web palsu untuk mendapatkan informasi data pribadi.

Yang ketiga, kami menanyakan perihal tahu atau tidaknya informan terhadap link phising yang dapat mencuri data pribadi. Keduanya kompak berkata "lya, tahu". Setelah itu, kami menanyakan tentang pengetahuan informan terhadap bahaya yang mengincar link phising yang tersebar. Ini bertujuan untuk mengetahui seberapa sadar para informan terhadap keamanan data pribadi. 
Jawaban yang dikemukakan oleh Informan A:

"Ancaman-ancaman yang berhubungan dengan hal-hal pribadi Seperti keuangan, identitas, dan hal hal mengatas namakan individu bersangkutan"

Dari jawaban diatas, dapat diketahui bahwa informan sadar akan pentingnya keamanan informasi pribadi. Para informan juga mengetahui bahwa ancaman-ancaman yang bisa timbul akibat terkena hoax link phising sangat merugikan, seperti masalah keuangan, identitas, dan penyalahgunaan data oleh pihak yang tidak bertanggung jawab. Ini sejalan dengan Rachmawati (2014:211) bahwa penjahat internet yang biasa disebut phisher biasanya mengancam data pribadi, seperti password akun dan nomor kartu kredit. Dampak-dampak negatif tersebut bisa timbul tidak hanya saat ini, tetapi juga bisa timbul pada masa yang akan datang.

Untuk mengetahui lebih jauh mengenai kesadaran mahasiswa Universitas Islam Nusantara terhadap keamanan informasi pribadi, kami menanyakan perihal langkah-langkah agar tidak ada lagi korban yang terkena link hoax tersebut.

Jawaban dari Informan A :

"Mencari tahu terkait informasi pembanding. Tidak langsung mengikuti tanpa ilmu"

Jawaban dari Informan B :

"Pengetahuan ict itu penting, jdi gada salahnya klo kita mempelajarinya, biar kita tau kalo yang ini bakalan berdampak gini, yang itu bakalan berdampak gitu, intinya pengetahuan itu penting"

Dari kedua jawaban diatas, dapat kita ketahui bahwa langkah agar tidak menjadi korban link phising adalah tidak ikut-ikutan dan langsung percaya terhadap informasi yang kita terima. Kita harus lebih waspada terhadap penyebaran link phising kuota Kemendikbud dan harus mengetahui ilmunya, khususnya pengetahuan akan Information communication technology yang akan sangat berguna untuk menjadi bekal di zaman sekarang ini. Menurut Rachmawati (2014:216) ada beberapa langkah agar bisa terhindar dari jebakan link phising, diantaranya adalah mengetik data pribadi pada website yang aman, waspada terhadap email yang tidak diminta, cermati alamat URL, dan menginstal anti virus juga patch keamanan pada komputer pribadi.

Kami juga menanyakan cara agar kita dapat mengenali link phising kuota kemendikbud menurut pendapat informan, dan jawaban informan adalah

Jawaban dari Informan A :

"Berpikir kritis dan skeptis"

Dari jawaban informan, ia berpendapat bahwa agar tidak menjadi korban link phising adalah dengan berpikir kritis dan waspada. Biasanya, web link phising mempunyai domain yang sangat mirip dengan web aslinya. Tetapi, kita dapat membedakannya dengan melihat web tersebut secara keseluruhan. Dimana, web palsu biasanya mempunyai tata letak dan user interface yang sangat buruk. Selain itu, domain web nya pun bisa sangat berbeda, dimana jika web asli dari kementrian biasanya menggunakan .Go.id sebagai domain resmi web nya, sedangkan web link phising menggunakan domain .co.id sebagai domainnya. Domain tersebut adalah domain gratis yang biasanya digunakan untuk kebutuhan pribadi dan organisasi non profit. Dari sini, dapat kita simpulkan bahwa kita harus berhati-hati dengan web-web yang kita masuki, karena web palsu sudah di desain sedemikian mirip untuk mengelabui para pengguna untuk masuk pada metode phising. Akan sangat berbahaya jika pengguna tidak cermat dalam mengakses internet dan masuk dalam perangkap phising (Irawan, 2020:46).

Terakhir, kami juga menanyakan seberapa sadar para informan setelah mengetahui pentingnya keamanan data pribadi, berikut dampak dan cara mencegahnya. Mereka berpendapat:

Jawaban yang dikemukakan oleh Informan A :

"Sangat sadar"

informan mengaku sangat sadar terhadap pentingnya keamanan data pribadi, di dukung dengan pengetahuan mengenai dampak-dampak yang akan ditimbulkan berikut cara mencegahnya. Ini menjadi hal yang sangat baik untuk para generasi muda yang sangat sadar akan keamanan data pribadi dan menjadi bekal untuk hidup di era serba teknologi seperti saat ini. Hal ini harus terus ditingkatkan dan di edukasi kepada masyarakat, mengingat web web palsu saat ini sudah semakin mirip dan membuat para korbannya tak sadar telah menjadi korban dan dirugikan (Irawan, 2020:44) 


\section{KESIMPULAN}

Dengan adanya perkembangan teknologi yang semakin pesat dan juga canggih ini memudahkan seseorang dalam melakukan sesuatu, tak terkecuali melakukan tindak kejahatan seperti pencurian data pribadi melalui iming-iming link phising kuota gratis. Berdasarkan data yang telah kami ambil data dari kedua informan kami dapat menyimpulkan bahwa informasi data pribadi sangat mudah untuk dicuri dengan perkembangan teknologi saat ini. Dan juga link phising ini menyebar kepada mahasiswa dengan sangat mudahnya melalui media sosial, dari beberapa informan mereka mengakui bahwa telah menerima link phising tersebut, ini membuktikan bahwa masih banyak sekali penyebaran-penyebaran link phising ini. Informasi data pribadi sangatlah penting, karena jika dengan diambilnya adanya data informasi pribadi oleh orang lain bisa jadi keamanan kita sendiri bisa terancam. Dengan adanya link phising ini kita di tuntut agar bisa lebih cermat, cerdas, dan juga waspada terhadap informasi yang ada seperti yang disampaikan para informan di atas dalam mengatasi penyebaran link phising tersebut.

\section{Referensi}

Aswandi, R., Muchin, P. R. N., \& Sultan, M. (2020). Perlindungan Data Dan Informasi Pribadi Melalui Indonesian Data Protection System (Idps). Jurnal Legislatif, 3(2), 169-170.

Budiarto, S. (2020). Strategi Pemasaran Dengan Menggunakan Pendekatan Mark Plus \& Co di Kandatel Jakarta. Jurnal Industri Elektro dan Penerbangan, 3(1). 16-17.

Fatimatus, zuria. S., \& Totok Suyanto. (2018). Kajian keterampilan intelektual mahasiswa UNESA dalam mengenali berita hoax di media sosial. Kajian Moral dan Kewarganegaraan, 6(2), 565-567.

Gumilang, G. S. (2016). Metode penelitian kualitatif dalam bidang bimbingan dan konseling. Jurnal Fokus Konseling, 2(2). 145-146.

Hardani, H. A., Ustiawaty, J., Istiqomah, R. R., Fardani, R. A., Sykmana, D. J., \& Auliya, N. H. (2020). Buku Metode Penelitian Kualitatif \& Kuantitatif. Yogyakarta: CV. Pustaka IImu Group.

Herlina, M., \& Lokananta, A. C. (2018). Dampak informasi hoax di media sosial terhadap tingkat konflik dan sikap pada remaja. Promedia (public relation dan media komunikasi), 4(2), 103-104.

Hulukati, W., \& Djibran, M. R. (2018). Analisis Tugas Perkembangan Mahasiswa Fakultas IImu Pendidikan Universitas Negeri Gorontalo. Bikotetik (Bimbingan dan Konseling: Teori dan Praktik), 2(1), 73-74.

Maulana, L. (2017). Kitab Suci dan Hoax: Pandangan Alquran dalam Menyikapi Berita Bohong. Wawasan: Jurnal Ilmiah Agama dan Sosial Budaya, 2(2), 210-211.

Pane, C. G. G. (2021). EDUKASI KEPADA SISWA SMA NEGERI 1 MIMIKA UNTUK MENGATASI ANCAMAN MEDIA ONLINE PADA DATA PRIBADI. KONSTELASI: Konvergensi Teknologi dan Sistem Informasi, 1(2), 417-418.

Rijali, A. (2019). Analisis data kualitatif. Alhadharah: Jurnal IImu Dakwah, 17(33), 84-85.

Valentina, E., \& Sari, W. P. (2019). Studi Komunikasi Verbal dan Non Verbal Game Mobile Legends: Bang Bang. Koneksi, 2(2), 301-302.

Wibowo, M. H., \& Fatimah, N. (2017). ANCAMAN PHISHING TERHADAP PENGGUNA SOSIAL MEDIA DALAM DUNIA CYBER CRIME. JOEICT (Jurnal of Education and Information Communication Technology), 1(1), 1-2.

Zaluchu, S. E. (2021). Metode Penelitian Di Dalam Manuskrip Jurnal IImiah Keagamaan. Jurnal Teologi Berita Hidup, 3(2), 256-257.

Juditha, Christian (2018) Interaksi Komunikasi Hoax di Media Sosial serta Antisipasinya Hoax Communication Interactivitu in Social Media and Anticipation, Jurnal Pekommnas, 17(1), 31-44

Rachmawati, D. (2014). Phising Sebagai Salah Satu Bentuk Ancaman Dalam Dunia Cyber. Jurnal SAINTIKOM Vol, 13(3), 211-216.

Irawan, D. (2020). MENCURI INFORMASI PENTING DENGAN MENGAMBIL ALIH AKUN FACEBOOK DENGAN METODE PHISING. JIKI (Jurnal IImu Komputer \& Informatika), 1(1). 45-46. 